\title{
Organic Farming: An Agricultural Waste Management System for Enhancing Soil Properties and Crop Yield
}

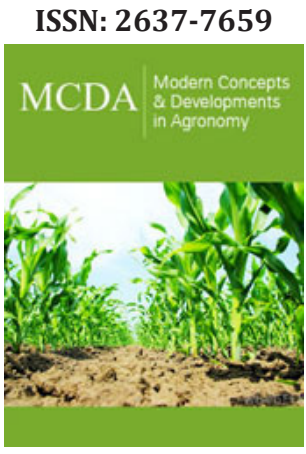

*Corresponding author: Oreva Oghene Aliku, Department of Agronomy, Faculty of Agriculture, University of Ibadan, Ibadan, Nigeria

Submission: 制 July 11, 2019

Published: 些July 18, 2019

Volume 4 - Issue 5

How to cite this article: Aliku 00 , Oshunsanya SO, Ikoko CB. Organic Farming: An Agricultural Waste Management System for Enhancing Soil Properties and Crop Yield. Mod Concep Dev Agrono.4(5). MCDA.000599.2019. DOI: 10.31031/MCDA.2019.04.000599

Copyright@ Oreva Oghene Aliku, This article is distributed under the terms of the Creative Commons Attribution 4.0 International License, which permits unrestricted use and redistribution provided that the original author and source are credited.

\author{
Aliku $\mathrm{O0}^{1 *}$, Oshunsanya $\mathrm{SO}^{1}$ and Ikoko $\mathrm{CB}^{2}$ \\ ${ }^{1}$ Department of Agronomy, Nigeria \\ ${ }^{2}$ Centre for Environmental Management and Control, Nigeria
}

\begin{abstract}
Sustainable agricultural production systems are crucial for meeting the food demand of the ever-increasing human population. However, these systems generate large amount of wastes which is a major environmental challenge when not properly managed. The difficulty and cost-related constraints associated with achieving sustainable food production through effective soil and crop management practices has led to a paradigm shift from inorganic farming to organic farming, where agricultural wastes are incorporated into the production systems. Organic farming applies natural principles for improved quality and quantity of crop produce while maintaining and/or improving soil health. This paper explores some ways in which agricultural wastes are used and their impacts on soil properties and crop yield in organic farming systems.
\end{abstract}

Keywords: Organic wastes; Environmental quality; Soil physical properties; Soil organic carbon; Crop yield

\section{Introduction}

Agriculture is very pivotal to human growth and development. This is due to the production of food and fiber which are needed by humans all over the world. However, agriculture is also associated with the production of large amount of wastes such as crop residues, animal manure, etc. [1]. These wastes are usually difficult to dispose and often reduces environmental aesthetics and quality as they are usually disposed on open fields or burnt in most parts of the world. Those left on the field encounter wetting and dry processes which may sometimes cause anaerobic conditions that lead to bad smell, attraction of flies and insects, and spread of epidemic diseases, while those burnt are usually associated with air pollution and release of obnoxious and greenhouse gases [2]. Aiyelari EA [3] explained that burning of agricultural wastes could be detrimental to human health and the environment owing to the release of greenhouse gases to the atmosphere which could also lead to global warming effects. Some consequences of this phenomenon may result into chaotic weather changes, food insecurity, starvation and malnutrition [4]. In recent years, agricultural production has advanced beyond the focus on great yield production to improved food quality, human nutrition and environmental quality via practices that improve environmental health, sound ecology, while enhancing food security. Rodale [5] advised that instead of focusing on greater yields in production agriculture, which will eventually exhaust soil nutrients, the goal should be an agricultural management system that has the capability to preserve or improve soil quality and the environment. Lokeshwari M [2] noted that most agricultural wastes contain biodegradable hemicellulose and cellulose materials, which on decomposition improve soil properties and supply nutrients to crops. Hence, they can be better managed by reusing and/ or recycling them. They may be used as a source of energy, bedding, manure, mulch, compost, organic matter, or plant nutrients which are environmentally friendly practices, or they can be marketable when properly treated $[3,6]$. A common practice is to recycle the nutrients in the waste through land application which is an alternative means of supplying nutrients to crops and maintaining soil fertility [6,7]. Hence, their use as a source of plant nutrients for growing vegetable crops could assume increasing importance as they are comparable to chemical fertilizers in crop yield improvement $[3,8]$. In general, all of these practices have been effectively coordinated under the umbrella of organic farming and have been reported as effective means of managing agricultural wastes for improvement of agricultural land while maintaining environmental quality. 


\section{Organic Farming}

This system makes the best use of crop residues, animal manure, green manure and off-farm organic waste in order to maintain soil productivity, supply plants with necessary nutrients, and control insects, weeds and other pests [9]. It is an agricultural waste management system in which all necessary components are installed and managed to control and use by-products of agricultural production in a manner that sustains or enhances the quality of air, water, soil, plant, animal and energy resources [6]. Organic farming, as a waste management system, consists of six basic functions as shown in Figure 1. Production is a function of the amount and nature of agricultural waste generated by an agricultural enterprise [6]. It varies with type, volume, time etc. The collection of these wastes involves capturing and gathering from point of deposition. The major problem with this as it affects environmental quality is that this aspect is given little or no consideration in most developing countries, including Nigeria. An agricultural waste management system should identify methods of collection, location of collection etc. [6]. Also, the transfer which involves the movement and transportation of waste from the collection point to storage, treatment and utilization site is very crucial. The mode and equipment for transfer will depend on the nature (liquid, semi-solid or solid) of the waste. This will also influence the type of storage facility and the processes required for treatment in order to reduce the pollution potential and/or modify the physical characteristics of the waste prior to utilization. Utilization of agricultural wastes has been reported to improve sanitary conditions, soil quality and crop yield [10]. Some of the soil properties and crop yield shown to be enhanced by use of some agricultural wastes under organic farming, and the forms in which these wastes were used are discussed as follows:

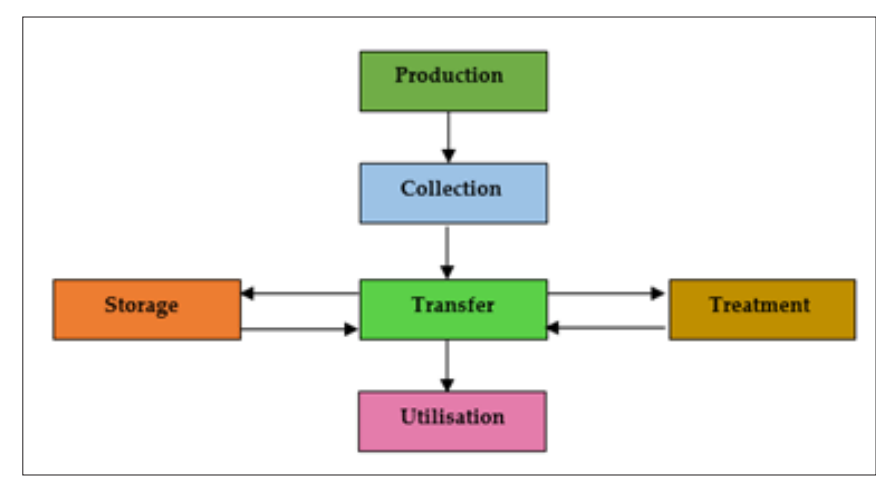

Figure 1: Agricultural waste management functions \{Adapted from [6]\}.

\section{Effects of organic farming on soil properties}

Table 1: Response of soil physical properties to organic and other forms of farming.

\begin{tabular}{|c|c|c|c|c|c|}
\hline \multirow{2}{*}{ Parameter } & \multirow{2}{*}{ Unit } & \multicolumn{2}{|c|}{ Farming System } & \multirow{2}{*}{$\%$ Difference } & \multirow{2}{*}{ Source } \\
\hline & & Organic (Type) & Others & & \\
\hline Bulk density & $\mathrm{Mg} \mathrm{m}^{-3}$ & 1.15 (FYM and compost) & 1.25 (NPK fertilizer) & 8.7 & [11] \\
\hline Bulk density & $\mathrm{Mg} \mathrm{m}^{-3}$ & 1.28 (Vermicompost) & 1.32 (Unamended soil) & 3.1 & [12] \\
\hline Water holding capacity & $\%$ & 51.6 (FYM and compost) & 46.4 (NPK fertilizer) & 5.2 & [11] \\
\hline Volumetric moisture content & $\%$ & 0.68 (Compost and $\mathrm{K}_{2} \mathrm{O}$ ) & 0.67 (NPK fertilizer) & 1.5 & [13] \\
\hline Mean weight diameter & $\mathrm{mm}$ & 0.95 (Not stated) & 0.73 (Not stated) & 30.1 & [14] \\
\hline Total porosity & $\%$ & 44.8 (1YACP) & 47.7 (2YACP) & 6.5 & [15] \\
\hline Hydraulic conductivity & $\mathrm{cm} \mathrm{hr}^{-1}$ & 59.2 (1YACP) & 56.7 (2YACP) & 4.4 & [15] \\
\hline
\end{tabular}

Values are mean across applications rates, soil depths or aggregate sizes; 1YACP: first year after compost application; 2YACP: second year after compost application.

Management of agricultural wastes via organic farming has been shown to improve several soil properties. This is due to alterations in soil physical properties, especially soil structural characteristics, which regulate soil functions and processes. Table 1 presents some results of responses of soil physical properties to organic farming. Papadopoulos A [11] reported that organic management significantly affects pore structure and enhances biological activities with positive effects on the environment. Comparing the impact of organic farming and conventional systems of coffee farming on soil properties, Velmourougane $\mathrm{K}$ [12] reported $8.4 \%$ increase in water holding capacity (WHC) under organic farming system of organic manure (5 tonnes farmyard manure and compost) relative to conventional method of N:P:K 40:30:40 (N:P205:K2O kg ha-1 per year). Earlier study by [13] reported improved soil WHC following application of residues and farmyard manure, while the application of vermicompost at $1 \mathrm{t} \mathrm{ha}^{-1}$ combined with farmyard manure and its sole application at $2.5 \mathrm{tha}^{-1}$ and $5 \mathrm{t} \mathrm{ha}^{-1}$ increased WHC and soil moisture content $[14,15]$.

This could be as a result of the affinity for water by organic matter which enhances the soil capacity to retain water for crop use, hence reducing the incidence of water loss through deep percolation and runoff. Krol A [16], in a 14-year study on organic farming and conventional farming systems, reported higher water infiltration following compost application than conventional farming of mineral fertilizer. They observed that the repellency index was mostly 
higher under the conventional farming system. Water repellent soil resists water infiltration and leads to surface runoff and infiltration [17]. Krol A [16] also observed that soil aggregate crushing strength was higher under the organic farming system than the conventional farming system. Nesic Lj [18] demonstrated that organic farming enhanced soil aggregate stability by recording higher mean weight diameter than conventional farming system. With respect to soil bulk density $(\rho b)$, the combination of composted coir pith and farmyard manure has also been reported to reduce $\rho b$ relative to unamended soil [19]. Soil bulk density was also lower under organic farming than conventional farming by $0.1 \mathrm{Mg} \mathrm{m}^{-1}[12]$. The combined effect of the internal aggregate strength and wettability can result to increased soil stability and water infiltration [20]. This could increase soil resistance to compaction and carbon sequestration.

Table 2: Soil chemical properties as influenced by organic and inorganic farming systems.

\begin{tabular}{|c|c|c|c|c|c|}
\hline \multirow{2}{*}{ Parameter } & \multirow{2}{*}{ Unit } & \multicolumn{2}{|c|}{ Farming System } & \multirow{2}{*}{$\%$ Difference } & \multirow{2}{*}{ Source } \\
\hline & & Organic (Type) & Others & & \\
\hline $\mathrm{pH}$ & - & 4.5 (FYM and compost) & 6.1 (NPK fertilizer) & 35.6 & [11] \\
\hline $\mathrm{pH}$ & - & 6.4 (Compost and $\mathrm{K}_{2} \mathrm{O}$ ) & 5.6 (NPK fertilizer) & 14.3 & [13] \\
\hline Organic carbon & $\%$ & 0.9 (Compost and $\mathrm{K}_{2} \mathrm{O}$ ) & 0.8 (NPK fertilizer) & 11.1 & [13] \\
\hline Aggregate associated organic matter & $\%$ & 3.7 (Not stated) & 2.7 (Not stated) & 37 & [14] \\
\hline Avail. $\mathrm{N}$ & $\mathrm{kg} \mathrm{ha}^{-1}$ & 346.0 (FYM and compost) & 307.5 (NPK fertilizer) & 12.5 & [11] \\
\hline Avail. P & $\mathrm{mg} \mathrm{kg}^{-1}$ & 23.5 (Green manure) & 21.2 (NPK fertilizer) & 10.8 & [23] \\
\hline Avail. K & $\mathrm{kg} \mathrm{ha}^{-1}$ & 363.5 (FYM and compost) & 344.5 (NPK fertilizer) & 5.5 & {$[11]$} \\
\hline Electrical conductivity & $\mathrm{dS} \mathrm{m}^{-1}$ & 0.91 (Green manure) & 1.22 (NPK fertilizer) & 34.1 & {$[23]$} \\
\hline
\end{tabular}

Values are means across applications rates, soil depths or aggregate sizes.

Table 3: Influence of organic and inorganic farming systems on soil biological properties.

\begin{tabular}{|c|c|c|c|c|c|}
\hline \multirow{2}{*}{ Parameter } & \multirow{2}{*}{ Unit } & \multicolumn{2}{|c|}{ Farming System } & \multirow{2}{*}{ \% Difference } & \multirow{2}{*}{ Source } \\
\hline & & Organic (Type) & Others & & \\
\hline Fungal count & $\times 105 \mathrm{cfu} \mathrm{g}^{-1}$ & 0.39 (Compost) & 0.31 (Unamended soil) & 25.8 & [15] \\
\hline No. of micro-arthropod & $\times 102 \mathrm{~m}^{-2}$ & 8.8 (Compost) & 8.7 (Unamended soil) & 1.1 & [15] \\
\hline Soil respiration & $\mathrm{CO}_{2} \mathrm{mg} / 50 \mathrm{~g}$ & 23.9 (FYM and compost) & 20.9 (NPK fertilizer) & 14.4 & [11] \\
\hline Urease & $\mu \mathrm{g} \mathrm{NH}_{4}-\mathrm{N} / \mathrm{g}^{-1} \mathrm{~h}^{-1}$ & 32.3 (FYM and compost) & 43.6 (NPK fertilizer) & 35 & {$[11]$} \\
\hline Fluorescein diacetate activity & $\mu \mathrm{g} / \mathrm{g}^{-1}$ & 39.0 (FYM and compost) & 28.2 (NPK fertilizer) & 38.3 & {$[11]$} \\
\hline
\end{tabular}

Values are mean across applications rates, soil depths or aggregate sizes.

The decomposition and mineralization of organic wastes usually result to alterations in the chemical constituents of soils. Several studies have demonstrated the effectiveness in the use of organic wastes as amendments in improving soil chemical properties (Table 2). This is largely affected by the type and amount of organic waste used. For instance, Gosling P [21] reported that there was no significant difference between an organically managed farm and conventional managed farm in organic matter content. In another study, however, Velmourougane K [12] reported significant increase in organic carbon under organic system of farm management. Based on a 50-year study, Blanchet G [22] demonstrated that incorporation of crop residues and farmyard manure increased soil organic carbon content by $2.45 \%$ and $6.40 \%$ compared to mineral fertilizer, respectively. The application of organic amendments such as crop residues and/or farmyard manure significantly increased soil organic carbon $[23,24]$. In major nutrients including nitrogen, phosphorus and potassium, Velmourougane $\mathrm{K}$ [12] reported an increase in nutrient levels under organic farming and conventional farming. They however noted a more pronounced inclination and availability under the conventional system. This could be due to the slow rate of decomposition of organic amendments. Bhogal A [25] explained that the variation in organic farming effects on soil chemical properties may be due to the rate and amount of organic matter added to the soil. The use of organic manure has been reported to give lower electrical conductivity (EC) when compared to the use of mineral fertilizer [12]. Though lower soil $\mathrm{pH}$ was reported for organic farming compared to conventional farming [12], the reverse was the order in Krol A [16]. This suggests that the effect of organic amendments on soil chemical properties depends on the type and amount. In terms of soil biological attributes (Table 3), [12] demonstrated that soil respiration and fluorescein diacetate activity were higher in organic managed farm relative to conventional farm. They also noted that organic system had higher macrofauna (31.4\%), microbial population (34\%), and microbial diversity indices compared to the conventional system of mineral fertilizer application. Although soil urease activity was 
higher under conventional farming system and the dehydrogenase activity showed no significant difference between the two systems, Velmourougane K [12] concluded that soil cultivated with coffee under long-term organic system has better soil properties than conventional farming system.

\section{Effects of organic farming on crop productivity}

The modification of soil properties by organic amendments in organic farming system often results to improved soil productivity and crop yield. Poultry manure and Terminalia catappa leaves compost was evaluated for it effect on okra (Abelmoschus esculentus) by Aiyelari EA [3] as shown in Table 4. They observed that the application of these organic wastes either as compost or mulch significantly improved okra pod yield. For example, 5t ha-1 and $10 \mathrm{t} \mathrm{ha}^{-1}$ compost of poultry manure and Terminalia catappa leaves gave $72.7 \%$ and $87.4 \%$ increase in the number of okra pods produced, while the use of Terminalia catappa leaves as mulch at $10 \mathrm{tha}^{-1}$ resulted to $1.0 \%$ increase. Corresponding values for fresh pod weight (g plant ${ }^{-1}$ ) were $204.4 \%$ and $267.0 \%$ increase under $5 \mathrm{t}$ $\mathrm{ha}^{-1}$ and $10 \mathrm{t} \mathrm{ha}^{-1}$ compost, while mulching at $5 \mathrm{t} \mathrm{ha} \mathrm{a}^{-1}$ and $10 \mathrm{t} \mathrm{ha}^{-1}$ gave $48.4 \%$ and $52.7 \%$ increase compared to unamended soil.

Table 4: Response of yield attributes of selected crops under organic farming system.

\begin{tabular}{|c|c|c|c|c|c|c|}
\hline \multirow{2}{*}{ Crop } & \multirow{2}{*}{ Yield Attribute } & \multirow{2}{*}{ Unit } & \multicolumn{2}{|c|}{ Farming System } & \multirow{2}{*}{$\%$ Difference } & \multirow{2}{*}{ Source } \\
\hline & & & Organic (Type) & Others & & \\
\hline Okra & No. of fruits & - & 19.0 (Compost) & 10.6 (Unamended soil) & 79.2 & [3] \\
\hline Okra & Fresh fruit weight & g plant $^{-1}$ & 678.9 (Compost) & 537.8 (NPK fertilizer) & 26.2 & [3] \\
\hline Rice & Grain yield & $\mathrm{t} \mathrm{ha}^{-1}$ & 3.50 (Mulch) & 1.77 (Unamended soil) & 97.7 & [29] \\
\hline Rice & Straw yield & tha $^{-1}$ & 4.83 (Manure) & 3.17 (Unamended soil) & 52.4 & [29] \\
\hline Pepper & Fresh fruit weight & g pot $^{-1}$ & 56.2 (Compost) & 55.1 (NPK fertilizer) & 2 & {$[30]$} \\
\hline Pepper & Shoot dry matter & g pot $^{-1}$ & 2.8 (Compost) & 2.6 (NPK fertilizer) & 7.7 & {$[30]$} \\
\hline
\end{tabular}

Values are mean across applications rates, soil depths or aggregate sizes.

However, some authors have demonstrated that the use of organic wastes as mulch offer little or no significant effect on crop yield. For instance, Gruber S [26] reported that mulching with wood chips had no effect on crop yield. Johnson JM [27] also reported that potato yields were similar in mulched and unmatched plots, but watermelon yield was higher in plots with straw mulch. Doring TF [28] reported no positive effect of straw mulch on potato yield due to the relatively low amounts of straw applied. Though Dauda BM [29] reported similar length of pepper fruit under grass mulch and unamended soil, they observed higher pepper yield in mulched plots than unmatched soil. Nasir M [30] reported that the average cucumber and bitter gourd yield was higher under mulch conditions compared to the control. The application of Gliricidia lopping's as mulch was reported to significantly enhance the dry fruit yield of chilli as compared to no unmatched treatment [31]. Cocoa husk mulch increased tomato fruits weight per plant compared to the control [32]. In comparison to mineral fertilizers, compost at 5 and $10 \mathrm{t} \mathrm{ha}^{-1}$ gave higher okra fresh pod weight than NPK fertilizer by 12.6 and $27.5 \%$, respectively [3]. In another study on swine manure composted with almond leaves, Ogunsesin A [33] reported that swine manure and almond leaves compost gave higher number of pepper fruits (16.8) than NPK 15 ${ }^{-1} 5-15$ fertilizer (15.5). They also noted that the organic amendment enhanced the nutritive components of pepper [34-37]. Thus, the impact of organic amendment applied as mulch could depend on the amount, nature and crop response under the prevailing environmental conditions.

\section{Conclusion}

Agriculture is associated with the production of large amount of organic wastes that can adversely affect environmental quality and human health if not properly managed. These wastes are biodegradable and rich in nutrient elements that are essential for enhancing soil fertility and crop growth. Therefore, management functions involving the collection, transfer, storage, treatment and utilization of agricultural wastes in organic farming could enable farmers harness the bio-fertilizer potentials in these wastes for agricultural crop production. Their utilization as compost, green manure and farmyard manure improves soil water holding capacity, saturated hydraulic conductivity, organic matter and total nitrogen content, microbial population and crop yield relative to conventional use of chemical fertilizers which are expensive. Thus, the alteration of agricultural wastes and their use as soil amendments would make them easy to handle and environmentalfriendly, hence making organic farming an environmentally sound production system for improving soil properties and crop yield. However, the role of organic farming in managing soil erosion is yet to be fully explored.

\section{References}

1. Oshunsanya SO, Aliku O (2016) Biochar technology for sustainable organic farming. In: Organic farming-A Promising Way of Food Production 6: 12-29.

2. Lokeshwari M, Swamy CN (2010) Waste to wealth-Agriculture solid waste management study. Poll Res 29(3): 129-133. 
3. Aiyelari EA, Ogunsesin A, Adeoluwa 00 (2011) Effects of Terminalia catappa leaves with poultry manure compost, mulching and seedbed preparation on the growth and yield of okra (Abelmoschus esculentus L. Moench). Proceedings of International Soil Tillage Research Organization. Ogunlela AO (Ed.), University of Ilorin, Nigeria pp. 356370 .

4. Preston TR, Leng RA (1989) The greenhouse effect and its implication for world agriculture. The need for environmentally friendly development. Livestock Res Rural Dev 1(1): 1-4.

5. Rodale Institute (2011) Report: 30 Years of the farming systems trial.

6. USDA-NRCS (2011) Agricultural waste management systems Agricultural waste management field handbook 651(9): 31.

7. Agboola AA, Ray PA, Unamma (1994) Maintenance of soil fertility under traditional farming systems. In: Lombin (Ed.), Organic fertilizer in the Nigerian Agriculture, present and future. Proceedings of a National Organic Fertilizer Seminar Kaduna, Nigeria.

8. Vincent BO, Micheals TM, Stanley MM (2005) Effect of cattle manure application on yield and yield indices of okra (Abelmoschus esculentus L. Moench). J Food Agric Environ 3: 125-129.

9. Lampkin NH (1990) Organic Farming. Farming Press, UK.

10. Ekwue EI (1992) Effect of organic and fertilizer treatments on soil physical properties and erodibilities. Soil Till Res 22(3-4): 199-209.

11. Papadopoulos A, Bird NRA, Whitmore AP, Mooney SJ (2006) The effect of organic farming on the soil physical environment. Aspects Appl Biol 79: 263-267.

12. Velmourougane K (2016) Impact of organic and conventional systems of coffee farming on soil properties and culturable microbial diversity. Scientifica p. 9.

13. Sharma MP, Bali SV, Gupta DK (2000) Crop yield and properties of inceptisol as influenced by residue management under rice-wheat cropping sequence. J Indian Soc Soil Sci 48(3): 506-509.

14. Jadhav SB, Jadhav MB, Joshi VA, Jagatap PB (1993) Organic farming in the light of reduction in use of chemical fertilizers. Proceedings of $43^{\text {rd }}$ Annual Deccan Sugar Technology Association, Pune Part I, India, pp. 5365.

15. Patil SL (1998) Response of rabi sorghum [Sorghum bicolor (L.) Moench] to tillage, moisture conservation practices, organics and nitrogen in Vertisols of semiarid tropics. University of Agricultural Sciences, Dharwad, Karnataka, India.

16. Krol A, Lipiec J, Turski M, Kus J (2013) Effects of organic and conventional management on physical properties of soil aggregates. Int Agrophys 27: 15-21.

17. Hallett PD, Baumgartl T, Young IM (2001) Subcritical water repellency of aggregates from a range of soil management practices. Soil Sci Soc Am J 65(1): 184-190.

18. Nesic Lj, Belic M, Savin L, Ciric V, Stefanovcic M, et al. (2014) Effect of organic production on soil structure. Bulg J Agric Sci 20(5): 1168-1174.

19. Rajkhannan B, Balasundaram CS, Baskar A, Selvi D (2001) Residual effect of tillage systems coupled with organics on soil physical properties after groundnut in a sandy clay loam having ruff soil hard pan. Madras Agric J 88(1-3): 63-69.

20. Eynard A, Schumacher TE, Lindstrom MJ, Malo DD, Kohl RA (2006) Effects of aggregate structure and organic $C$ on wettability of Ustolls. Soil Till Res 88: 205-216.
21. Gosling P, Shepherd M (2005) Long-term changes in soil fertility in organic arable farming systems in England, with particular reference to phosphorus and potassium. Agric Ecosys Environ 105(1-2): 425-432.

22. Blanchet G, Gavazov K, Bragazza L, Sinaj S (2016) Responses of soil properties and crop yields to different inorganic and organic amendments in a Swiss conventional farming system. Agric Ecosys Environ 230: 116-126.

23. Diacono M, Montemurro F (2010) Long-term effects of organic amendments on soil fertility. A review. Agron Sustain Dev 30(2): 401422 .

24. Maltas A, Charles R, Jeangros B, Sinaj S (2013) Effect of organic fertilizers and reduced-tillage on soil properties, crop nitrogen response and crop yield: results of a 12-year experiment in Changins, Switzerland. Soil Till Res 126: 11-18.

25. Bhogal A, Nicholson FA, Chambers B (2008) Organic carbon additions: effects on soil bio-physical and physico-chemical properties. European J Soil Sci 60(2): 276-286.

26. Gruber S, Achraya D, Claupein W (2008) Wood chips used for weed control in Organic Farming. J Plant Diseases Protection 21: 401-406.

27. Johnson JM, Hough Goldstein JA, Vangessel MJ (2004) Effects of straw mulch on pest insects, predators, and weeds in watermelons and potatoes. Environ Ent 33(6): 1632-1643.

28. Doring TF, Brandt M, HeB J, Finckh MR, Saucke H (2005) Effects of straw mulch on soil nitrate dynamics, weeds, yield and soil erosion in organically grown potatoes. Field Crops Res 94(2-3): 238-249.

29. Dauda BM (2012) Effects of grassed and synthetic mulching materials on growth and yield of sweet pepper (Capsicum annum) in Mubi, Nigeria. J Agric Soc Sci 8(3): 97-99.

30. Nasir M, Moazzam A, Shahbaz A, Zakaullah I (2011) Effect of mulching on vegetables production in tunnel farming. Mycopath 9(1): 21-24.

31. Venkanna Y (2008) Studies on the effect of mulches, organics and organic solutions on growth, yield and quality of chilli Cv. Byadagi Dabbi in Northern Transition Zone of Karnataka. M. Sc. (Agri.) Thesis. University of Agricultural Science, Dharwad, India, p. 128.

32. Ojeniyi SO, Awodun MA, Odedina SA (2007) Effect of animal manure, amended spent grain and cocoa husk on nutrient status, growth and yield of tomato. International Journal of Agricultural Research 2(4): 3336.

33. Ogunsesin A, Aiyelari EA (2017) Effect of swine manure with Terminalia catappa leaves compost and NPK fertiliser on growth and yield of pepper (Capsicum chinense Jacq.) in Ibadan, Nigeria. International J Sci Res Publications 7(12): 417-426.

34. Patil PV, Chalwade PB, Solanke AS, Kulkarni VK (2003) Effect of fly ash and fym on physico-chemical properties of vertisols. J Soils Crops 13(1): 59-64.

35. Babalola OA, Adesodun JK, Olasantan FO, Adekunle AF (2012) Responses of some soil biological, chemical and physical properties to short-term compost amendment. Int J Soil Sci 7(1): 28-38.

36. Gasparatos D, Roussos PA, Christofilopoulou E, Haidouti C (2011) Comparative effects of organic and conventional apple orchard management on soil chemical properties and plant mineral content under Mediterranean climate conditions. J Soil Sci Plant Nutrition 11(4): 105-117.

37. Gaire R, Dahal KR, Amgain LP (2013) Effect of different mulching materials on weed dynamics and yield of direct seeded rice in Chitwan, Nepal. Agron J Nepal 3: 73-81. 